\title{
Morphological diversity patterns among selected elite Shea trees (Vitellaria paradoxa C.F. Gaertn.) from Tchologo and Bagoué districts in Northern Côte d'Ivoire
}

\author{
YAO Saraka Didier Martial ${ }^{1 *}$, DIARRASSOUBA Nafan ${ }^{1}$, ATTIKORA Affi Jean Paul ${ }^{2}$, FOFANA \\ Inza Jesus ${ }^{1}$, DAGO Dougba Noel ${ }^{1}$ and SILUE Souleymane ${ }^{1}$ \\ ${ }^{1}$ Département Biochimie-Génétique, University of Peleforo Gon Coulibaly (UPGC), UFR Sciences Biologiques, \\ Unité Pédagogique et de Recherche (UPR) de Génétique, BP 1328 Korhogo, Côte d'Ivoire. \\ ${ }^{2}$ University of Liège, Gembloux Agro-Bio-Tech, Passage des Déportés, 2 B-5030 Gembloux, Belgium.
}

Received 9 December, 2019; Accepted 21 January 2020

\begin{abstract}
Agromorphological diversity structure of the elite shea trees identified in village lands and conserved in situ in the districts of Bagoue and Tchologo by the shea breeding program of the University of Peleforo Gon Coulibaly (UPGC, Côte d'Ivoire), are not known. In the present study, we characterized the agromorphological parameters of 220 elite shea trees using a set of 12 quantitative traits. The results showed that elite shea trees population has been structured into three morphological clusters or genetic pools that do not overlap with the original geographic areas. Morphological Cluster I contain elite shea trees with small trunk diameters carrying large leaves and producing fewer fruits per tree. Morphological Cluster II consisted of elite shea trees with stronger trunks bearing small leaves and producing a high number of fruits per tree. Morphological Cluster III regrouped elite shea trees of medium trunk diameters carrying medium sized leaves; fruit production level is intermediate compare to preceding groups. The elite shea trees of morphological Clusters II, which are more interesting from an agronomic point of view, can be used as grafting trees for the production of high-yielding grafted plants for farmers in Côte d'Ivoire.
\end{abstract}

Key words: elite shea trees, genetic improvement, phenotypic variability, Northern Côte d'Ivoire.

\section{INTRODUCTION}

Vitellaria paradoxa C.F. Gaertn., commonly known as 'shea butter tree' or 'shea tree' in English and 'karité' in French, is a plant species of the Sapotaceae family that grows naturally in Sudano-Sahelian belt of Africa (Hall et al., 1996; Diarrassouba et al., 2007). The geographical distribution of shea tree extends from Senegal to Uganda at latitudes between $2^{\circ}$ and $8^{\circ}$ North in East Africa, $7^{\circ}$ and $12^{\circ}$ North in Central Africa and $9^{\circ}$ and $14^{\circ}$ North in

${ }^{*}$ Corresponding author. E-mail: didierys@yahoo.fr. Tel: +225 04737926.

Author(s) agree that this article remain permanently open access under the terms of the Creative Commons Attribution License 4.0 International License 
West Africa (Naughton et al., 2015). The large distribution of shea doubled by practicing allogamy as a mode of reproduction suggests a high intra-specific diversity (Diarrassouba et al., 2007). It is already reported the existence of two subspecies within the species $V$. paradoxa that are paradoxa and nilotica (Gwali et al., 2014). Butter of the western subspecies paradoxa, present in Côte d'Ivoire, is rich in stearic acid and gives a solid oil calling butter at ambient temperature, while the oil from the eastern subspecies nilotica is especially rich in oleic acid with liquid oil at ambient temperature. The species is widely known for its oil from nut which is used in cooking, cosmetics and traditional medicine (Diarrassouba et al., 2009a; Soro et al., 2011). The marketing of almonds and butter on local markets provides substantial income for women who are involved in the sector (Diarrassouba et al., 2008).

Despite the economic importance of shea butter as a multipurpose product, the erosion of genetic diversity and density of shea trees in natural agroforestry park is increasing over time. The cumulative effects of violent wind uprooting trees, the cutting downs for household needs, plowing for the installation of fields and the systematic collecting of fruits in natural parks by rural populations limit natural regeneration of shea trees (Boussim, 1991; Senou, 2000; Diarrassouba et al., 2009a). To overcome these problems, progressive domestication and genetic improvement of the species are being considered. Previous research has focused on fruit production (Lamien, 2006; Aleza et al., 2018), vegetative propagation (Bonkoungou et al., 1988), molecular diversity of populations (Bouvet et al., 2004; Fontaine et al., 2004; Sanou et al., 2005; Gwali et al., 2014 ; Abdulai et al., 2016), the spatial structure of populations (Kelly et al., 2004; Sanou et al., 2006, Aleza et al., 2015), the parasitism of the shea trees (Bayala et al., 2009; Samaké et al., 2011), the variability of fruit yields (Lamien et al., 2007; Bondé et al., 2019), etc. In Côte d'Ivoire especially, researches on V. paradoxa by Salé et al. (1991) reported that some characters such as fruit number, leaf and fruit size, leaf density, flowering and fruit ripening times are related to nut and butter yields. Also, in an agroforestry park of shea trees only $26 \%$ of trees are good producers and $15 \%$ of them have stable production (Salé et al., 1991). Similarly, quantitative and qualitative traits have proved highly relevant for probing morphological diversity in park of shea trees in Tengrela in Northern Côte d'Ivoire (Diarrassouba et al., 2007; Diarrassouba et al., 2009b). Only from qualitative morphological traits related to fruits and leaves, five morphological varieties of shea tree have been identified in the shea tree park at Tengrela (Diarrassouba et al., 2009b). The research activities carried out in the context of vegetative propagation enable breeding program of the shea tree of Côte d'Ivoire to multiply grafted plant materials and disseminate selected elite shea trees in village lands (Yao et al., 2019).
However, in the light of previous researches, there are still questions about the best ways and means of conserving shea genetic resources and improving the productivity of this species. Until today, the agromorphological characteristics of elite shea trees, identified in village terroirs and preserved in situ in the Bagoué and Tchologo districts, are not known in Côte d'Ivoire. Such knowledge would make help to set up breeding program of shea tree in Côte d'lvoire and to judiciously involve the identified elite individuals in the subsequent hybridization plans for the creation of improved plant material. This study aims to know phenotypic diversity patterns among selected elite plant from Tchologo and Bagoué districts constituting the in situ collection of shea trees in Northern Côte d'Ivoire, using quantitative agromorphological traits.

\section{MATERIALS AND METHODS}

\section{Study area}

The study was conducted in the administrative districts of Bagoué and Tchologo (Figure 1). The districts of Tchologo and Bagoué are located in Northern Côte d'Ivoire between $9^{\circ} 31$ 'and $9^{\circ} 35^{\prime}$ North latitude and $5^{\circ} 11$ 'and $6^{\circ} 29^{\prime}$ 'West longitude.

\section{Ecological zones of districts and departments selected for the study}

The Northern region of Côte d'Ivoire (Figure 1) has a Sudano Guinean climate characterized by two major seasons. The dry season runs from November to April and the rainy season covers the period from May to October. The rainy season has an annual rainfall of around 1, $200 \mathrm{~mm}$ per year (Brou, 2005). The vegetation is of Sudano Guinean type with gallery forests along the rivers and a predominance of wooded and grassy savannas (N'Guessan et al., 2015). The geological formations of the zone consist of a succession of bands of schistose rocks, magmatic rocks and plutonic rocks from which several types of soils are derived, namely Ferralsols, Cambisols, Fluvisols and Luvisols (Yace, 2002; Kone et al., 2009).

\section{Plant material}

The study was conducted on 220 elite shea trees constituting the in situ collection of the University of Peleforo Gon Coulibaly (UPGC) (Figure 1). The elite shea tree is a natural tree presenting good agronomic characteristics in village lands and recognized by the famers themselves basing on theirs knowledges about shea tree. Like that, the elite shea trees were identified according participatory method by the farmers from a survey based on criteria such as the high fruit yield of tree, the sweet taste of the fruit pulp, the high size of the fruit, the early flowering every year and the regularity of production of the tree. The survey was conducted by the shea breeding program of UPGC, Côte d'Ivoire in collaboration with Agence Nationale d'Appui au Développement Rural (ANADER, Côte d'Ivoire). The elite shea trees were selected in four localities that are Tengrela (73 trees), Kouto (50 trees), Boundiali (23 trees), Ferkéssédougou (21 trees), Ouangolodougou (12 trees) and Kong (41 trees).

\section{Morphological parameter measurements}

The data was collected on elite shea trees during the period of 


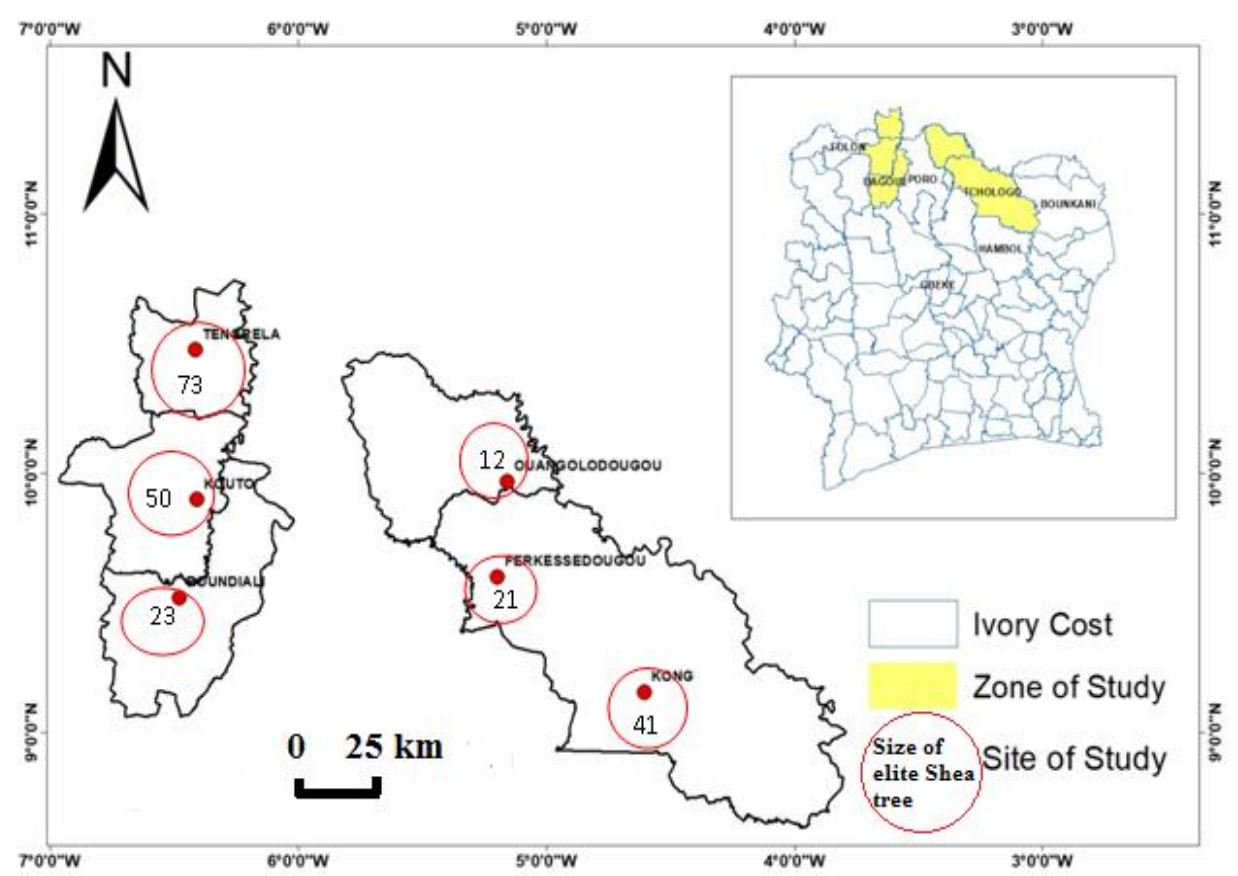

Figure 1. Study site maps showing Bagoué and Tchologo districts and sample size of observed elite shea trees.

Source: Shea breeding program of UPGC, Côte d'Ivoire, December (2019).

Table 1. Measured morphological traits, codes and unity.

\begin{tabular}{lll}
\hline Traits (SI Unity) & Code & Unity (SI) \\
\hline Girth of trunk & $\mathrm{GT}$ & $\mathrm{cm}$ \\
Petiole length & $\mathrm{PL}$ & $\mathrm{cm}$ \\
Limb length & $\mathrm{LL}$ & $\mathrm{cm}$ \\
Limb width & $\mathrm{LW}$ & $\mathrm{cm}$ \\
Limb length/Limb width ratio & $\mathrm{LL} / \mathrm{LW}$ & - \\
Fruit per tree & $\mathrm{FT}$ & Unit \\
Nut per fruit & $\mathrm{NF}$ & Unit \\
Nut length & $\mathrm{NL}$ & $\mathrm{cm}$ \\
Nut width & $\mathrm{NW}$ & $\mathrm{cm}$ \\
Nut lenght/Nut width ratio & $\mathrm{NL} / \mathrm{NW}$ & - \\
Nut volume & $\mathrm{NV}$ & $\mathrm{cm}^{3}$ \\
Nut weight & $\mathrm{NWG}$ & $\mathrm{g}$ \\
\hline
\end{tabular}

fruiting (May to July 2017), to characterize both vegetative aspects (trunk and leaf) and some descriptors related to the fruits. A total of 12 agromorphological quantitative traits were evaluated (Table 1, Figure 2). Quantitative traits such as girth of trunk, petiole length, limb length, limb width, fruit per tree, nut per fruit, nut length, nut width and nut weight were measured directly on the tree. For nut per fruit, nut length, nut width and nut weight evaluations ten nuts were considered per tree and the average values were retained. Thus the nuts extracted per well-developed fruit (when they fall down) were count. The length and width of each extracted nuts were measured using a sliding caliper type tool. The weight of each extracted nuts was assessed using an electronic scale. The parameters such as Limb length/Limb width ratio, Nut length/Nut width ratio and nut volume were calculated. The shape of the shea nut has been assimilated to a cylinder and its volume (NV) has been determined according to the mathematical expression:

$N V=\pi \times r^{2} \times h$

where $r^{2}=\mathrm{NW} / 2, \mathrm{~h}=\mathrm{NL}$ and $\pi=3.14$.

\section{Data analysis}

First, data collected on elite shea trees have been submitted to a descriptive statistic analysis. The minimum, maximum and mean 

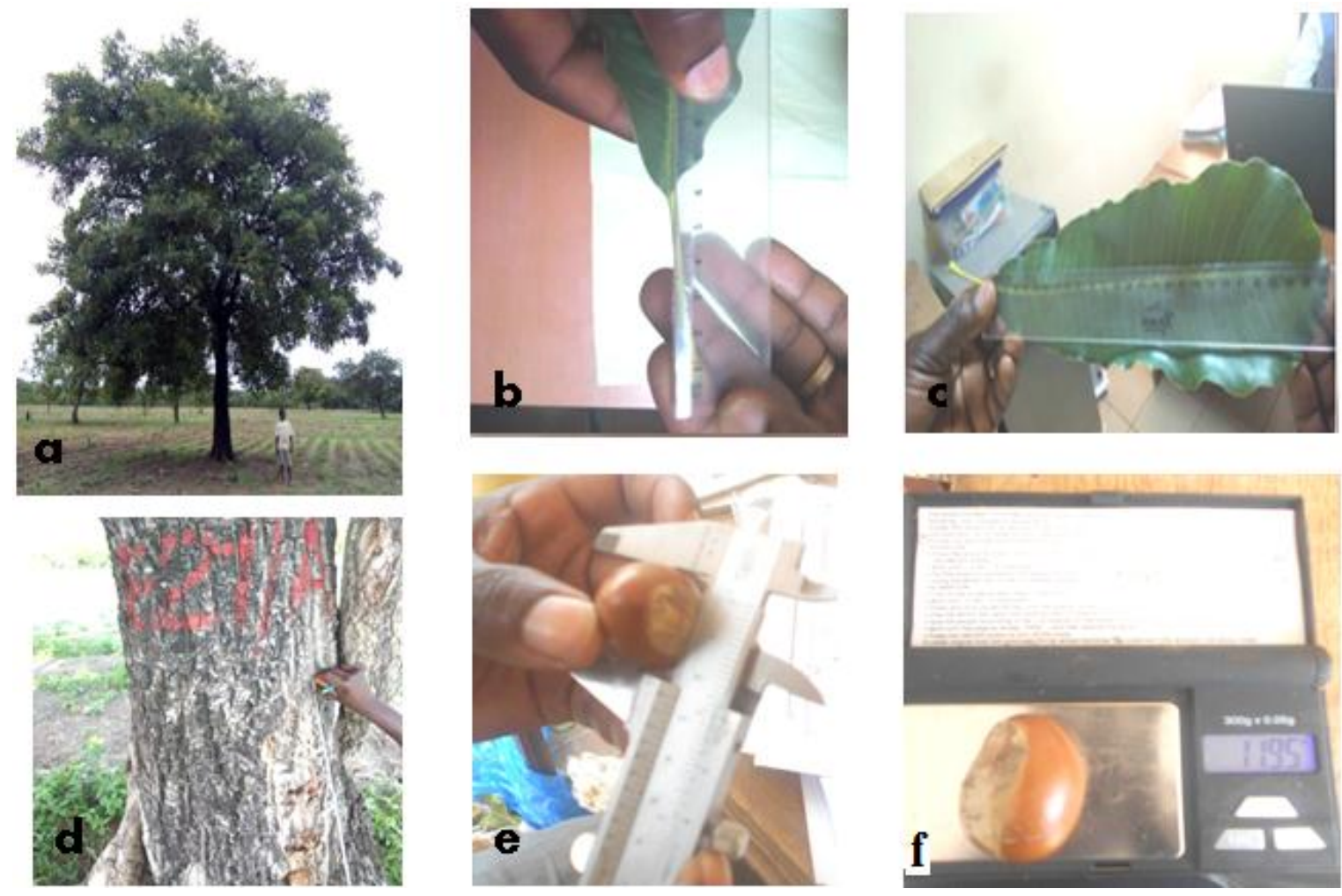

Figure 2. Measures of morphological traits on the trunk, leaf and the seed of elite shea trees in the Bagoué and Tchologo districts, Northern Côte d'Ivoire. (a) Elite shea tree at the field, (b and c) Leaf size measures, (d) Measure of girth of trunk at $130 \mathrm{~cm}$ above the soil level (e and f). Measures of nut size and nut weight.

values, standard deviations and coefficients of variation have been determined for all quantitative traits. Then, a multiple analysis of variance (MANOVA) has been realized. This analysis was performed from all studied agromorphological traits and has been done in order to test the significance of all studied traits for elite shea trees discrimination when "district" or "department" was fixed as factor. Once the significance of the effect of the "district or department" factor is verified, the specific traits that contributed to the difference between localities (district or department) were identified from t-test when two districts (Bagoué vs. Tchologo) are compared and analysis of variance (ANOVA) when comparisons were done between six departments (Tengrela, Kouto, Boundiali, Ferkessedougou, Ouangolodougou and Kong) at the risk threshold of $5 \%$. Any significant ANOVA $(p<0.05)$ was followed a postANOVA test like Student Newman Keuls (SNK) test. Before MANOVA and ANOVA tests, the normality of each quantitative trait was verified from Shapiro-Wilk test at $5 \%$ of probability. Finally, the structure of the morphological diversity of elite shea trees was done from Principal Component Analysis (PCA), Hierarchical Classification Analysis (HCA) and Discriminant Analysis (DA). For PCA, the first four principal components were retained. Cluster analysis (Unweighted Pair Group Method Analysis, UPGMA) was performed using the matrix of average population values based on the elite shea tree's matrix of means. The clusters were then represented in a dendrogram. Also, the Pearson correlations between the morphological characters were revealed from Heat map using a quick and semi-automatic computational bio-statistical pipeline developed by Dago et al. (2019) in a simple programming language with $\mathrm{R}$ software. The other statistical analyzes were carried out using STATISTICA version 7.1 (StatSoft Inc., France) and SPSS version 20 (IBM Corp., USA) softwares.

\section{RESULTS}

\section{Morphological variability of elite shea trees}

The multiple analysis of variance (MANOVA) showed that all 12 variables made distinctions between the elite shea trees of two districts at the scale of the districts (Wilks'Lambda test; $\mathrm{F}=4.100 ; \mathrm{p}<0.001$ ) (Table 2). Likewise, at the scale the department, differences between six departments were observed with all studied traits (Wilks'Lambda test; $F=3.100 ; p<0.001$ ) (Table 2). Among the agromorphological traits that contributed to the structure of elite shea trees per district or department, the highly significant differences were observed in the expression of trunk girth $(61$ to $287 \mathrm{~cm})$, the fruit number per tree (241 to 3903 fruits.tree $\left.{ }^{-1}\right)$ and the nut weight (1.05 to $17.92 \mathrm{~g}$ ) (Table 2).

Principal Component Analysis (PCA) identified four factors accounting for $75.95 \%$ of the variability observed among elite shea trees. The first identified factor accounting for $30.48 \%$ of the total variability reflects the nut size. The second identified factor accumulates $18.02 \%$ of the variability and defines the trunk robustness and fruit yield per tree. The third factor captured $15.01 \%$ of the variability and essentially explains the nut shape. The fourth factor identified accounted for $12.38 \%$ of the 
Table 2. Variations in the trait expression in elite Shea trees and associated MANOVA, Student and ANOVA tests from district and department factors in Northern Côte d'Ivoire.

\begin{tabular}{|c|c|c|c|c|c|c|}
\hline \multirow[t]{2}{*}{ Traits (SI Unity) } & \multirow[t]{2}{*}{ Mean } & \multirow[t]{2}{*}{ Range } & \multicolumn{2}{|c|}{$\begin{array}{c}\text { t-test with factor } \\
\text { district }\end{array}$} & \multicolumn{2}{|c|}{$\begin{array}{c}\text { ANOVA test with factor } \\
\text { department }\end{array}$} \\
\hline & & & $\mathbf{F}$ & $p$-value & $\mathbf{F}$ & $p$-value \\
\hline Girth of trunk (cm) & 149.25 & $50.00-287.00$ & 18.63 & $<0.001$ & 18.69 & $<0.001$ \\
\hline Petiole length (cm) & 8.50 & $5.18-29.42$ & 4.92 & 0.027 & 1.71 & 0.131 \\
\hline Limb length (cm) & 14.84 & $9.34-21.58$ & 4.28 & 0.039 & 2.77 & 0.018 \\
\hline Limb width $(\mathrm{cm})$ & 4.58 & $2.82-9.94$ & 5.87 & 0.016 & 1.71 & 0.133 \\
\hline Limb length/Limb width ratio & 3.28 & $1.10-4.83$ & 1.57 & 0.211 & 1.76 & 0.120 \\
\hline Fruit per tree & 1774.51 & $241.00-3903.00$ & 18.63 & $<0.001$ & 18.69 & $<0.001$ \\
\hline Nut per fruit & 1.02 & $1.00-2.00$ & 3.51 & 0.062 & 1.89 & 0.097 \\
\hline Nut length $(\mathrm{cm})$ & 3.18 & $2.26-6.60$ & 5.29 & 0.022 & 3.83 & $<0.01$ \\
\hline Nut width $(\mathrm{cm})$ & 2.38 & $1.21-3.15$ & 3.85 & 0.051 & 2.71 & 0.021 \\
\hline Nut length/Nut width ratio & 1.34 & $1.06-2.94$ & 1.26 & 0.260 & 1.15 & 0.335 \\
\hline Nut volume $\left(\mathrm{cm}^{3}\right)$ & 14.44 & $2.63-26.34$ & 8.51 & 0.033 & 4.73 & $<0.01$ \\
\hline Nut weight (g) & 8.96 & $1.05-17.92$ & 14.73 & $<0.001$ & 6.17 & $<0.001$ \\
\hline Wilks'Lambda test & - & - & 4.10 & $<0.001$ & 3.10 & $<0.001$ \\
\hline
\end{tabular}

Table 3. Factor loadings in the first four factor components.

\begin{tabular}{lcccc}
\hline Factor components & First & Second & Third & Fourth \\
\hline Eigenvalues & 3.65 & 2.17 & 1.80 & 1.48 \\
Variance (\%) & 30.48 & 18.08 & 15.01 & 12.38 \\
Cumulative variance (\%) & 30.48 & 48.56 & 63.57 & 75.95 \\
Girth of trunk & -0.38 & 0.74 & 0.33 & 0.00 \\
Petiole lengh & 0.39 & -0.36 & 0.13 & 0.31 \\
Limb lengh & 0.42 & -0.52 & 0.26 & 0.28 \\
Limb width & 0.31 & -0.47 & 0.37 & -0.57 \\
Limb lenght/Limb width ratio & 0.05 & 0.04 & -0.13 & 0.96 \\
Fruit per tree & -0.38 & 0.75 & 0.33 & 0.00 \\
Nut per fruit & 0.38 & 0.03 & 0.48 & -0.08 \\
Nut lenght & 0.70 & 0.32 & -0.57 & -0.14 \\
Nut width & 0.85 & 0.31 & 0.27 & 0.04 \\
Nut lenght/Nut width ratio & 0.07 & 0.07 & -0.84 & -0.19 \\
Nut volume & 0.92 & 0.34 & -0.06 & -0.04 \\
Nut weight & 0.86 & 0.30 & 0.09 & 0.04 \\
\hline
\end{tabular}

total variability and reflected leaf shape (Table 3).

The analysis of the heat map revealed four categories of studied traits: (i) the trunk girth and the fruit number per tree, (ii) the nut length / nut width and limb length / limb width ratio, (iii) nut size (NV, NWG, NW and NL) and (iv) leaf size (LL, LW and LP) and nut number per fruit (see color key in Figure 3). Positive correlations were revealed within the descriptors of each identified category. In these categories, the strongest positive correlations were recorded in categories (i) and (iii). The highest correlation $(r=0.98)$ was obtained between the trunk girth at $130 \mathrm{~cm}$ (GT 130) and the fruit number per tree (fruit / tree). Highly significant values $(p<0.001)$ of positive correlations were also observed between nut weight and nut width $(r=0.80)$, between nut weight and nut length $(r=0.58)$ and between nut weight and nut volume $(r=0.84)$. For foliar characteristics, the longer leaf is wider ( $r=0.56, p=0.01$ ) also (see color key in Figure 3).

\section{Morphological clusters of elite shea trees}

The Hierarchical Classification Analysis (HCA) of the 220 elite of shea trees performed according to the Unweighted Pair Group Method Analysis (UPGMA) 


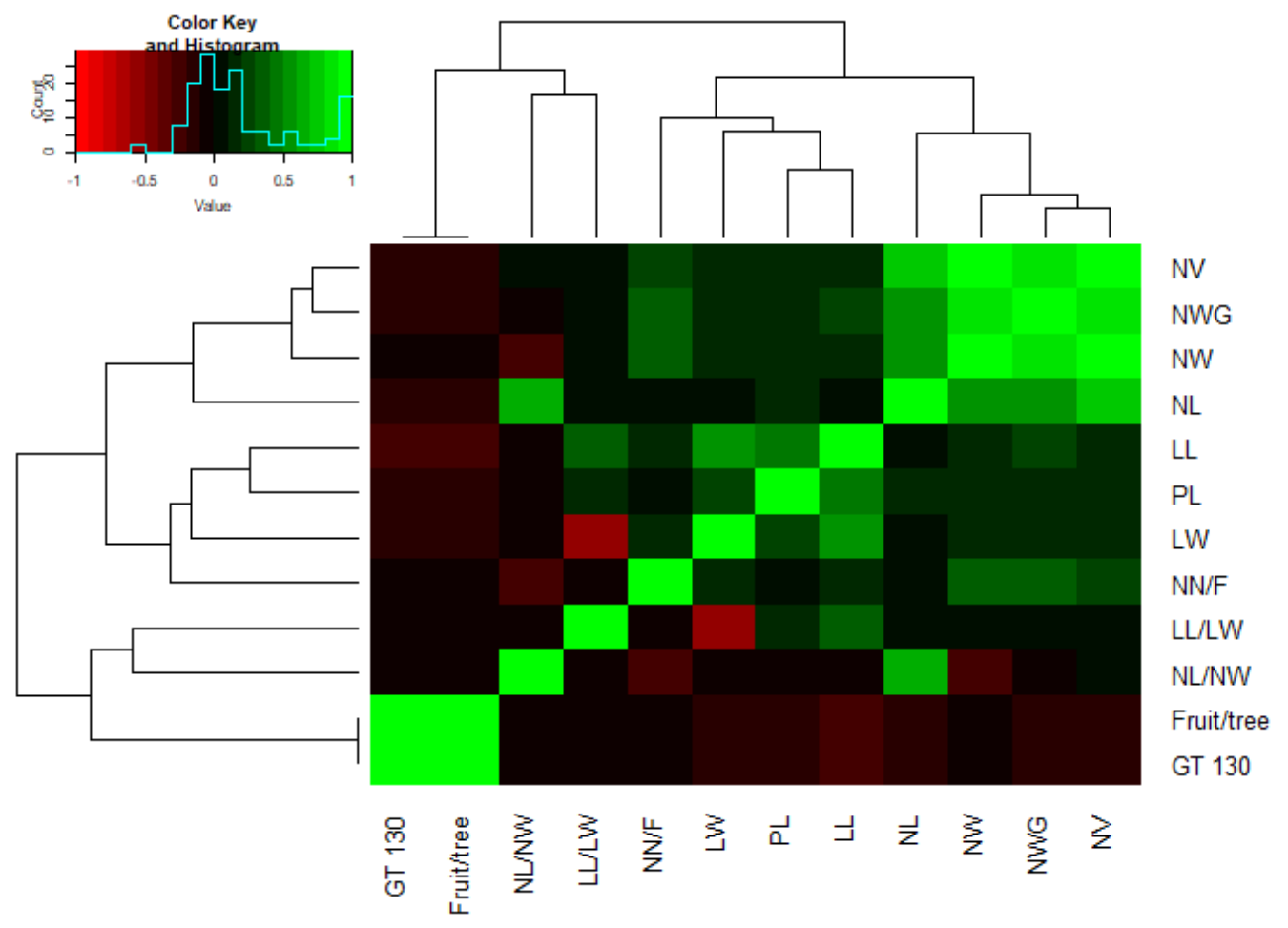

Figure 3. Pearson correlation heat map showing relationships between morphological traits measured on elite shea trees in Bagoué and Tchologo districts in Northern Côte d'lvoire. GT 130: Girth of trunk at $130 \mathrm{~cm}$ above the soil; PL: Petiole lengh; LL: Limb lengh; LW: Limb width; LL/LW: Limb lenght/Limb width ratio; FT: Fruit per tree; NF: Nut per fruit; NL: Nut length; NW: Nut width; NL/NW: Nut lenght/Nut width ratio; NV: Nut volume; NWG: Nut weight.

aggregation criterion from the Euclidean distances of the quantitative traits revealed three morphological clusters (Figure 4). The multiple analysis of variance (MANOVA) performed on these clusters from the set of 12 studied morphological traits showed a significant difference (Wilks'Lambda test; $F=20.22 ; p<0.001$ ) (Table 4). Morphological cluster I consisted of 139 elite shea trees, of which 83 were from the Bagoue district and 56 elite shea trees coming from Tchologo district. Elite shea trees of morphological cluster I have small trunk diameters $(121.21 \pm 26.73 \mathrm{~cm})$ with large leaves $(15.21 \pm 2.45 \mathrm{~cm}$ limb length and $4.69 \pm 0.73 \mathrm{~cm}$ limb width) and producing less fresh fruits per tree $(1341 \pm 413$ fruits per tree) (Table 4 , and Figure 5). Morphological cluster II consisted of 16 elite shea trees that represent $7.27 \%$ of studied sample: 10 trees from Bagoué and 6 trees from Tchologo. Trees of morphological cluster II express high values of trunk diameter $(244.56 \pm 20.98 \mathrm{~cm})$ carrying small leaves $(13.66 \pm 1.68 \mathrm{~cm}$ limb length and $4.17 \pm 0.84 \mathrm{~cm}$ limb width) and producing a high number of fresh fruits per tree (3247 \pm 324.26 fruits per tree) (Table 4 and Figure 5 ). Morphological cluster III contains 65 elite shea trees or $29.54 \%$ of all studied elite shea trees with 53 and 12 from Bagoué and Tchologo districts respectively. Elite shea trees from morphological cluster III express medium values of trunk diameter $(185.78 \pm 14.56 \mathrm{~cm})$ with medium-sized leaves $(14.34 \pm 2.15 \mathrm{~cm}$ limb length and $4.45 \pm 1.04 \mathrm{~cm}$ limb width) and an intermediate fruit production ( $2339 \pm 225$ fresh fruits per tree) in relation to the two preceding morphological clusters (Table 4 and Figure 5).

\section{DISCUSSION}

The agromorphological diversity study is important approach for the management of plant genetic resources. Likewise, Djekota (2014) reported that agromorphological approach constitutes the first step to start shea tree selection. For a long time, shea resources management has been mainly based on the classification of farmers for the conservation, domestication and selection (Lovett and Haq, 2000). However, these local knowledges retained for shea elite trees must necessarily be refined by scientifically proven knowledge in order to optimize improvement strategies for the species (Masters, 2002).

The agromorphological traits measured on the trunk, leaves and fruits showed significant variations between districts or even departments in Northern Côte d'Ivoire. These results suggest the significant influence of the environment on the expression of morphological characters in shea tree. These results can be explained 


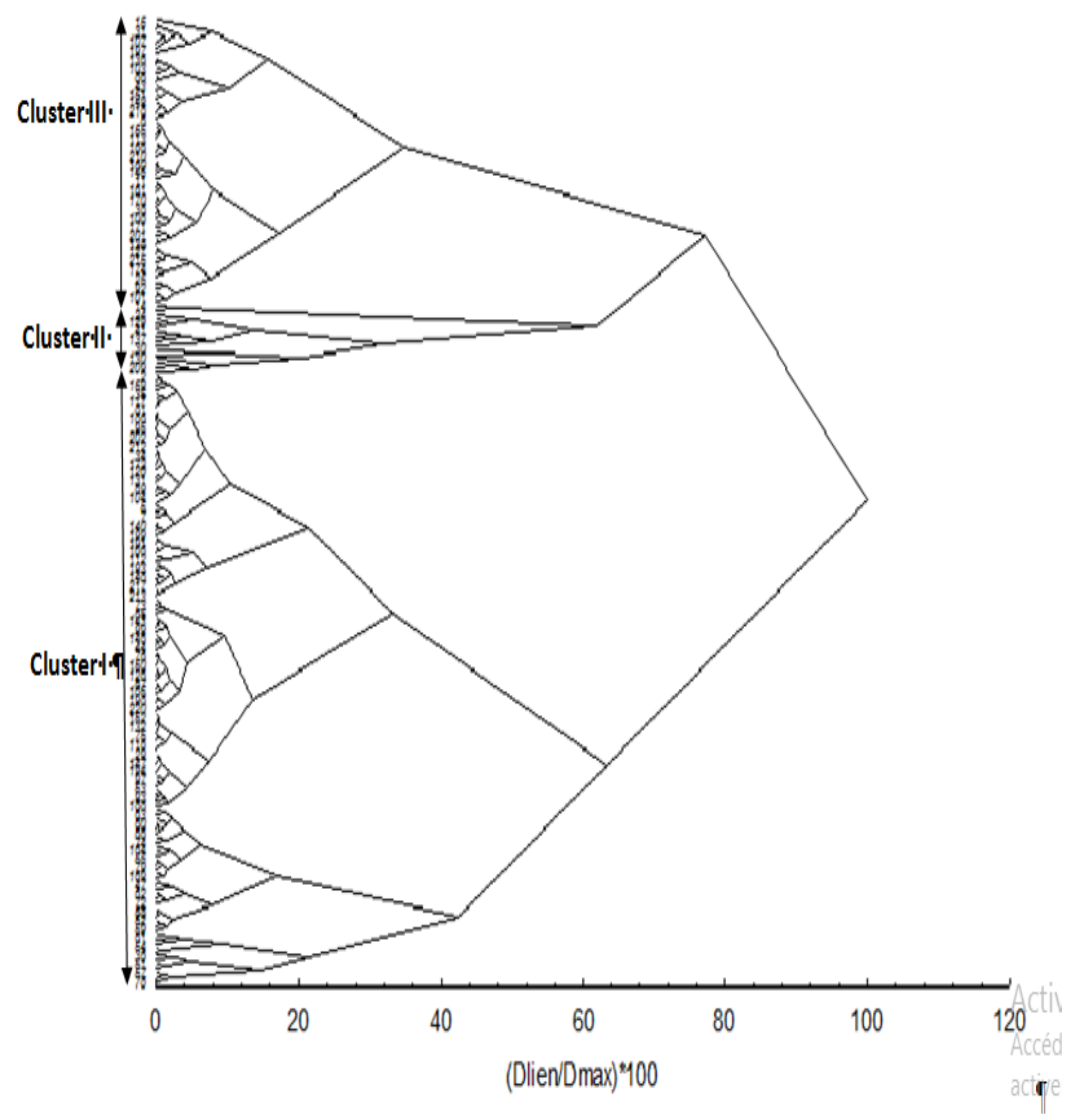

Figure 4. Dendrogram UPGMA of 220 elites shea trees in Bagoué and Tchologo districts, Northern Côte d'Ivoire.

Table 4. Characteristics of three morphological clusters identified from Hierarchical Cluster Analysis within 220 elite shea trees in Northern Côte d'Ivoire.

\begin{tabular}{|c|c|c|c|c|c|}
\hline \multirow{2}{*}{ Traits (SI Unity) } & \multicolumn{3}{|c|}{ Means \pm standart deviation } & \multirow{2}{*}{$\mathbf{F}$} & \multirow{2}{*}{ p-value } \\
\hline & Cluster I (N=139) & Cluster II ( $\mathrm{N}=16)$ & Cluster III (N=65) & & \\
\hline Girth of trunk $(\mathrm{cm})$ & $121.21 \pm 26.73^{\mathrm{C}}$ & $244.56 \pm 20.98^{a}$ & $185.78 \pm 14.56^{\mathrm{b}}$ & 311.91 & $<0.001$ \\
\hline Petiole lengh (cm) & $8.73 \pm 2.34^{a}$ & $7.74 \pm 1.08^{\mathrm{a}}$ & $8.21 \pm 1.52^{\mathrm{a}}$ & 2.59 & 0.077 \\
\hline Limb lengh $(\mathrm{cm})$ & $15.21 \pm 2.45^{\mathrm{a}}$ & $13.66 \pm 1.68^{b}$ & $14.34 \pm 2.15^{\mathrm{ab}}$ & 5.41 & 0.005 \\
\hline Limb width (cm) & $4.69 \pm 0.73^{\mathrm{a}}$ & $4.17 \pm 0.84^{b}$ & $4.45 \pm 1.04^{\mathrm{ab}}$ & 3.84 & 0.022 \\
\hline Limb lenght/Limb width ratio & $3.26 \pm 0.41^{\mathrm{a}}$ & $3.34 \pm 0.44^{\mathrm{a}}$ & $3.30 \pm 0.54^{a}$ & 0.31 & 0.726 \\
\hline Fruit per tree & $1341.00 \pm 413.00^{c}$ & $3247 \pm 324.26^{\mathrm{a}}$ & $2339.00 \pm 225.00^{b}$ & 311.91 & $<0.001$ \\
\hline Nut per fruit & $1.02 \pm 0.75^{\mathrm{a}}$ & $1.02 \pm 0.42^{\mathrm{a}}$ & $1.02 \pm 0.78^{\mathrm{a}}$ & 0.12 & 0.887 \\
\hline Nut lenght (cm) & $3.22 \pm 0.44^{a}$ & $3.19 \pm 0.22^{a}$ & $3.10 \pm 0.31^{a}$ & 1.95 & 0.144 \\
\hline Nut width $(\mathrm{cm})$ & $2.39 \pm 0.24^{a}$ & $2.39 \pm 0.14^{a}$ & $2.36 \pm 0.20^{\mathrm{a}}$ & 0.41 & 0.667 \\
\hline Nut lenght/Nut width ratio & $1.35 \pm 0.18^{a}$ & $1.33 \pm 0.06^{a}$ & $1.31 \pm 0.10^{\mathrm{a}}$ & 1.32 & 0.266 \\
\hline Nut volume $\left(\mathrm{cm}^{3}\right)$ & $14.74 \pm 4.04^{\mathrm{a}}$ & $14.47 \pm 2.43^{\mathrm{a}}$ & $13.80 \pm 3.20^{a}$ & 1.39 & 0.249 \\
\hline Nut weight $(\mathrm{g})$ & $9.11 \pm 2.81^{a}$ & $9.08 \pm 1.74^{\mathrm{a}}$ & $8.62 \pm 2.11^{a}$ & 0.84 & 0.432 \\
\hline Wilks'Lambda test & - & - & - & 19.22 & $<0.001$ \\
\hline
\end{tabular}

by a savannah gradient observed in the localities of study. In fact, on the ecological level, the Sudanese and Sudano-Guinean savannah are encountered in the study area (Bagoué and Tchologo). The climatic characteristics of these two savannah types being not similar would be at the origin of the environmental effects observed in the 


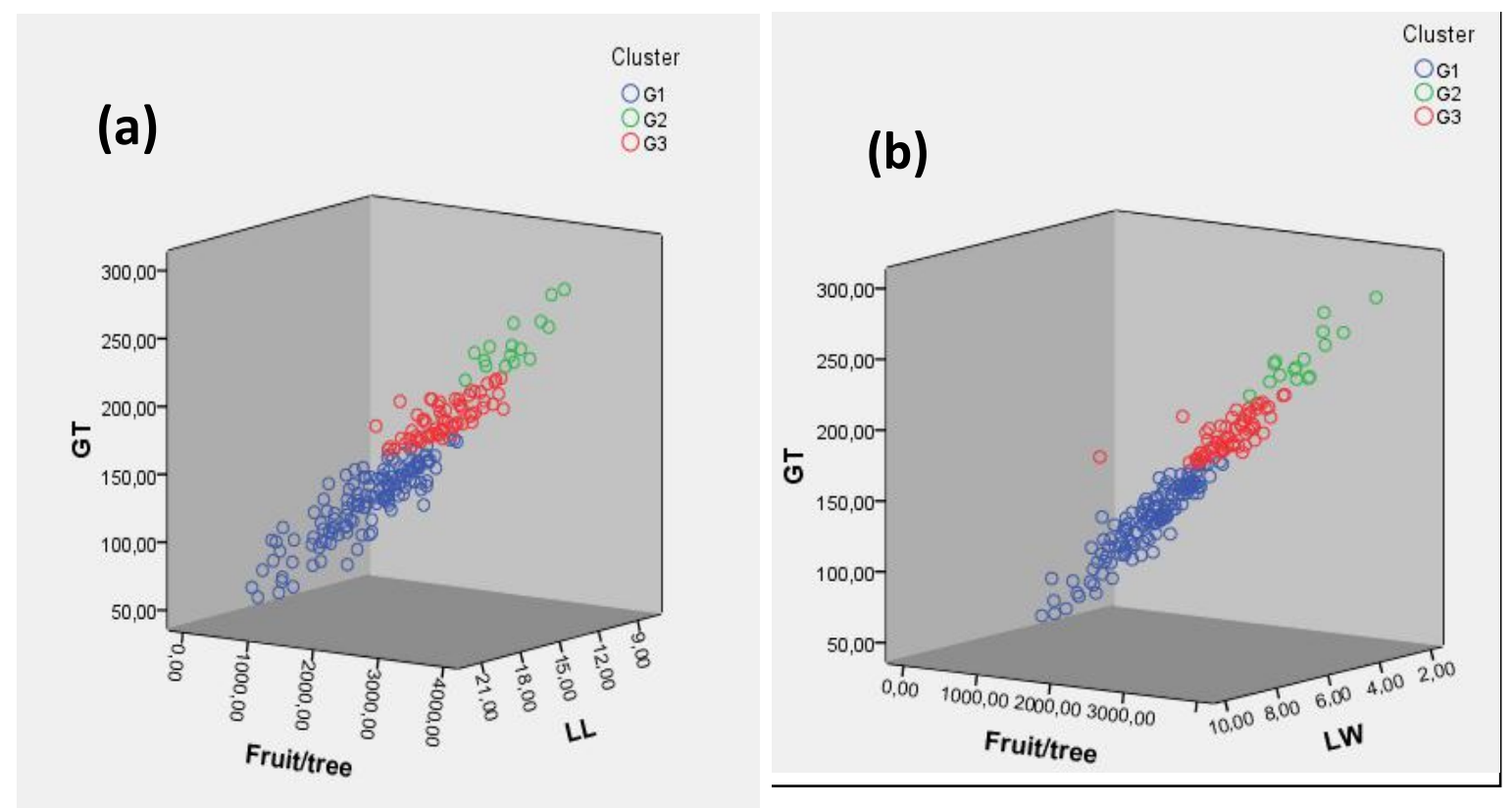

Figure 5. 3-D Scatter showing morphological diversity structure of the three clusters in the space formed from axes (X) Fruit per tree, (Y) Girth of trunk and (Z) Limb length or Limb width. GT: Girth of trunk at $130 \mathrm{~cm}$; LL: Limb lengh; LW: Limb width; FT: Fruit per tree.

variation of the morphological characters expression as reported by McGowen et al. (2010). The impacts of climate on the expression of morphological characters have also been reported in Northern Equator (Maranz and Wiesman, 2003), Mali (Sanou et al., 2006; Tchabi and Adechi, 2014), Benin (Kougblénou et al., 2012; Kafilatou et al., 2015) and Uganda (Gwali et al., 2012). Moreover, in area of study the mineral composition of the soil, varying from one ecological zone to another, would have also influenced the expression of morphological characters as reported by Sanou et al. (2006), Moore (2008) and Bondé et al. (2019) respectively in studies on the vegetative characteristics of shea tree parks in Mali, Eastern Ghana and West Africa. The environmental effect significantly influencing the expression of agromorphological characters in shea tree can lead to a possible structuring of elite shea trees according to districts or departments. But, analysis of the diversity of all the elite shea trees without prior fixing of the district or department factors gave three morphological clusters. These morphological clusters do not correspond to the geographical structuring of the identified elite shea trees. These results would indicate that the geographic zone factor alone cannot constitute the basic factor in the structuring of identified elite shea trees. Indeed, the natural and human selections could be at the origin of these groupings. The selection of elite trees based on farmers' preferences would have led to the selection of trees with identical performances from one locality to another (Gwali et al., 2012; Karambiri et al., 2016). Similarly, the allogamous nature of shea tree has been found to cause important gene flow between populations (Vaughan et al., 2007; Abasse et al., 2011). This would have led to similar morphological characteristics of shea trees from one locality to another.

The results show that the variability factors reflecting the dimensions of the nut, although more important in explaining the variability in the shea tree, did not make it possible to differentiate the three morphological clusters of elite trees identified in the Bagoué and Tchologo districts. The three morphological clusters differed mainly in the girth of trunk and the number of fruits per tree and secondarily in the size of the leaves. These results demonstrate that girth of trunk could be a good indicator for selection of producing trees, especially since a higher correlation $(r=0.99)$ was obtained between trunk girth and fruit number per tree. In the study areas, elite shea trees are spared and maintained by the farmers during agricultural practices according to preference criteria such as the taste of the pulp, the fruit size and the oil content. This way of phenotypic selection made by farmers in village lands would have led to retaining elite trees or semi-domesticated trees with similar performances depending on the characteristics of the nut.

The results reveal four categories of studied traits presenting significant positive interrelationships between them: (i) the trunk girth and the fruit number per tree, (ii) the nut length / nut width and limb length / limb width ratio, (iii) nut size (NV, NWG, NW and NL) and (iv) leaf size (LL, LW and LP) and nut number per fruit. This result indicates that the use of a single pomological descriptor such as the nut width is sufficient to characterize the 
shea nut. For example there are $80 \%$ odds to make a good estimate of the nut weight by referring to its width. Also, a single foliar descriptor such as the leaf length can be retained to discriminate populations of shea trees. Similarly, there is a significant correlation between trunk girth and fruit number per tree. This positive correlation indicates that fruit yield increases with the tree robustness. Meanwhile the increase of the fruit production is not linear with the age of the shea tree. Indeed, Nouvellet et al. (2006) showed that old shea tree individuals with big diameter are less or not productive compare to young ones with medium diameter in shea trees park of Ténéfina, Mali. Thus, the correlations found in the categories of characters highlighted in the present study in shea tree have already been mostly reported in the earlier works of Diarrassouba et al. (2007). Taking correlations into account may reduce the number of descriptors as the biological information provided by two positively correlated descriptors is similar as reported by Yao et al. (2015) concerning the coconut trees.

\section{Conclusion}

This study was conduct with a view to characterize the morphological diversity of selected elite shea trees identified in the Bagoue and Tchologo districts of Côte d'Ivoire. The results revealed three morphological clusters of elite shea trees from Bagoué and Tchologo districts in Northern Côte d'Ivoire. While waiting to use these three gene pools for hybrid creation, individuals of morphological cluster II showing attractive agronomic performances, can serve as graft-producing trees for the production of high-yielding grafted plants in Côte d'Ivoire.

\section{CONFLICT OF INTERESTS}

The authors have not declared any conflict of interests.

\section{ACKNOWLEDGEMENTS}

The authors would like to thank Fond Interprofessionnel pour la Recherche et le Conseil Agricole (FIRCA) for the financial support obtained through the project $\mathrm{N}^{\circ}$ 069/FIRCA/UFR-UPGC/ KARITE/ RE /2016 concerning the Identification and characterization of elite shea trees in production area in Côte d'Ivoire.

\section{REFERENCES}

Abasse T, Weber J, Katkore B, Boureima M, Larwanou M, Kalinganire A (2011). Morphological variation in Balanites aegyptiaca fruits and seeds within and among parkland agroforests in eastern Niger. Agroforestry Systems 81(1):57-66.

Abdulai I, Krutovsky KV, Finkeldey R (2016). Morphological and genetic diversity of shea tree (Vitellaria paradoxa) in the savannah regions of Ghana. Genetic Resources and Crop Evolution 64(6):1253-1268.
Aleza K, Wala K, Bayala J, Villamor GB, Dourma M, Atakpama W, Akpagana K (2015). Population structure and regeneration status of Vitellaria Paradoxa C. F. Gaertn under different land management regimes in Atacora department, Benin. Agroforestry Systems 89(3):511-523.

Aleza K, Villamor GB, Nyarko BK, Wala K, Akpagana K (2018). Shea (Vitellaria paradoxa C. F. Gaertn) fruit yield assessment and management by farm households in the Atacora district of Benin. PLOS ONE 13(1).

Bayala J, Ky-Dembélé C, Boussim IJ (2009). Technique de Taille Sylvicole pour la Lutte Contre les Parasites Loranthaceae et l'Amélioration de la Production Fruitière du Karité. Fiche Technique, INERA, Burkina Faso.

Bondé L, Ouédraogo O, Ouédraogo I, Thiombiano A, Boussim I (2019). Variability and estimating in fruiting of shea tree (Vitellaria paradoxa C.F. Gaertn.) associated to climatic conditions in West Africa: implications for sustainable management and development. Plant Production Science 22(2):143-158.

Bonkoungou E, Zerbo J, Billan A (1988). Multiplication végétative du karité (Butyrospermum paradoxum) au Burkina Faso. In: IRBRTISNIIDR, 1988. Séminaire national sur la valorisation du karité pour le développement national. Bilan et perspectives, pp 45-54.

Boussim I (1991). Contribution à l'étude des Tapinanthus Parasites du karité au Burkina Faso. Thèse de Doctorat $3^{\text {eme }}$ Cycle, Université de Ouagadougou, Ouagadougou, Burkina Faso, 131p.

Brou YT (2005). Climat, mutations socio-économiques et paysages en Côte d'Ivoire. Mémoire de synthèse des activités Scientifiques présenté en vue de l'obtention de l'habilitation à diriger des recherches. Université des Sciences et Technologies de LILLE, France, p. 212.

Bouvet JM, Fontaine C, Sanou H, Cardi C (2004). An analysis of the pattern of genetic variation in Vitellaria paradoxa C. F. Gaertn. Using RAPD markers. Agroforestry Systems 60(1):61-69.

Dago DN, Fofana IJ, Diarrassouba N, Barro ML, Moroh JL, Dagnogo O, Loukou NE, Yao SDM, Silué S, Giovanni M (2019). A Quick Computational Statistical Pipeline Developed in $\mathrm{R}$ Programing Environment for Agronomic Metric Data Analysis. American Journal of Bioinformatics Research 9(1):22-44.

Diarrassouba N, N'guessan A, Koffi E, Sangaré A (2007). Evaluation des performances de quelques descripteurs quantitatifs et leur utilisation dans la structuration de la population d'un parc naturel de karité en Côte d'Ivoire. Plant Genetic Resource Newsletter 152:6572.

Diarrassouba N, Koffi KE, N'Guessan KA, Patrick V, Sangare A (2008). Connaissances locales et leur utilisation dans la gestion des parcs à karité en Côte d'Ivoire. Afrika Focus 21(1):77-96.

Diarrassouba N, Bup ND, Fofana IJ, Sangare A (2009a). Varieties fixing at shea trees (Vitellaria paradoxa C.F. Gaertn.) Using morphological traits in Côte d'Ivoire. Geneconserve 8(33):752-780.

Diarrassouba N, Fofana JI, Bakayoko A, Nguessan AK, Sangare A (2009b). Influence des systèmes agraires sur la dynamique de régénération naturelle du karité : Vitellaria paradoxa C.F. Gaertn. (Sapotaceae) en Côte d'Ivoire. Agronomie Africaine 21(1):49-58.

Djekota C (2014). Etude de la variabilité morphologique et taxonomique des morphotypes chez le karité (Vitellaria paradoxa C.F. Gaertn. sous-espèce paradoxa. Sapotaceae) dans la région du Mandoul au Tchad. Thèse de Doctorat, Université Cheikh Anta Diop de Dakar, Sénégal, p. 151.

Fontaine C, Lovett PN, Sanou H, Maley J, Bouvet JM (2004). Genetic diversity of the shea tree (Vitellaria paradoxa C.F. Gaertn) detected by RAPD and chloroplast microsatellite markers. Heredity 93(6):639-648.

Gwali S, Nakabonge G, Okullo JBL, Eilu G, Nyeko P, Vuzi P (2012). Morphological variation among shea tree (Vitellaria paradoxa subsp. nilotica) 'ethnovarieties' in Uganda. Genetic Resources and Crop Evolution 59(8):1883-1898.

Gwali S, Vaillant CA, Nakabongea G, Okulloa J, Eilua G, Muchugid A, Bouvet C J (2014). Genetic diversity in shea tree (Vitellaria paradoxa subspecies nilotica) ethno-varieties in Uganda assessed with microsatellite markers. Forests Trees and Livelihoods 24(3):163-175.

Hall JB, Aebischer DP, Tomlison HF, Osei-Amaning E, Hindle JR (1996). Vitellaria paradoxa: A monograph Vitellaria paradoxa: a 
monograph (Publication No. 8). University of Wales. Bangor, UK: School of Agricultural and Forest Sciences.

Kafilatou ST, Léonard AE, Vincent E, Eliassou SH (2015). Agromorphological variability of shea populations (Vitellaria paradoxa CF Gaertn) in the Township of Bassila. Benin Republic. Journal of Plant Breeding and Crop Science 7(2):28-37.

Karambiri M, Elias M, Vinceti B, Grosse A (2016). Exploring local knowledge and preferences for shea (Vitellaria paradoxa) ethnovarieties in Southwest Burkina Faso through a gender and ethnic lens. Forests, Trees and Livelihoods 26(1):13-28.

Kelly BA, Bouvet JM, Picard N (2004). Size class distribution and spatial pattern of Vitellaria paradoxa in relation to farmers' practices in Mali. Agroforestry System 60(1):3-11.

Kone B, Diatta S, Sylvester O, Yoro G, Mameri C, Desiré DD, Ayemou A (2009). Estimation de la fertilité potentielle des ferralsols par la couleur. Canadian Journal of Soil Science 89(3):331-342.

Kougblénou N, Ahouansou RH, Aïssi MV, Houssou P, Padonou W, Fandohan P, Mensah GA, Soumanou MM (2012). Caractérisation physique du fruit et valeur nutritionnelle de la pulpe de karité (Vitellaria paradoxa) collecté dans différents parcs au Bénin. Bulletin de la Recherche Agronomique du Bénin, pp. 1840-7099.

Lamien N (2006). Fructification du karité (Vitellaria paradoxa Gaertn.F.. Sapotaceae): Facteurs de déperdition. Amélioration et Prévision des rendements à Bondoukuy. Ouest du Burkina Faso. Thèse de Doctorat, Université de Ouagadougou, Burkina Faso, p. 108.

Lamien N, Tigabu M, Guinko S, Oden PC (2007). Variations in dendrometric and fruiting characters of Vitellaria paradoxa populations and multivariate models for estimation of fruit yield. Agroforestry System 69(1):1-11.

Lovett PN, Haq N (2000). Diversity of the Shea nut tree (Vitellaria paradoxa C.F. Gaertn.) in Ghana. Genetic Resources and Crop Evolution 47(3):293-304.

Maranz S, Wiesman Z (2003). Evidence for indigenous selection and distribution of the shea tree, Vitellaria paradoxa, and its potential significance to prevailing parkland savanna tree patterns in sub-Saharan Africa north of the equator. Journal of Biogeographie 30(10):1505-1516.

Masters E (2002). La ressource en karité: vue d'ensemble de la recherche et du développement en Afrique. Présentation à atelier international sur le traitement, la valorisation et le commerce du karité en Afrique. Centre de Suivi Ecologique Dakar, Sénégal du 4 au 6 mars 2002.

McGowen MH, Vaillancourt RE, Pilbeam DJ, Potts BM (2010). Sources of variation in self incompatibility in the Australian forest tree, Eucalyptus globulus. Annals of Botany 105 (5):737-745.

Moore S (2008). The role of Vitellaria Paradoxa in poverty reduction and food security in the Upper East region of Ghana. Earth and Environment 3:209-245.

Naughton CC, Lovett PN, Mihelcic JR (2015) Land suitability modeling of shea (Vitellaria paradoxa) distribution across sub-Saharan Africa. Applied Geography 58:217-22.

N'Guessan A, Diarrassouba N, Konan A, Nangha KY, Inza JF, Kouamé AY (2015). Indicateurs de dégradation physique des sols dans le nord de la Côte d'Ivoire : cas de Boundiali et Ferkéssédougou. Afrique Science 11:3.

Nouvellet $Y$, Kassamba A, Besse F (2006). Le parc à karité au Mali: inventaire, volume, houppiers et production fruitière. Bois et Forêts des Tropiques 287:6-20.

Salé G, Boussim J, Raynal-Roques A, Brunck F (1991). Le Karité une richesse potentielle. Perspectives de recherche pour améliorer sa production. Revue Bois et forets des Tropiques 28(2):11-23.
Samaké O, Dakouo JM, Kalinganire A, Bayala J, Bréhima K (2011). Techniques de déparasitage et gestion du karité. ICRAF Technical Manual No. 15. Nairobi: World Agroforestry Centre.

Sanou H, Lovett PN, Bouvet JM (2005). Comparison of quantitative and molecular variation in agroforestry populations of the shea tree (Vitellaria paradoxa C.F. Gaertn.) in Mali. Molecular Ecology 14(8):2601-2610.

Sanou H, Picard N, Lovett PN, Dembele M, Korbo A, Diarisso D, Bouvet JM (2006). Phenotypic variation of agromorphological traits of the shea tree, Vitellaria paradoxa C.F.Gaertn, in Mali. Genetic Resources and Crop Evolution 53(1):145-161.

Senou O (2000). Les peuplements de karité (Vitellaria paradoxa Gaertn C.F.) dans le cercle de Koutiala au Sud de Mali: répartition, structure et parasitisme par les Tapinanthus. Mémoire de DEA, Université de Ouagadougou, Burkina Faso, p. 84.

Soro D, Traore K, Kassi NJ (2011). Variabilité des caractères morphologiques chez le karité (Vitellaria paradoxa) dans le Nord de la Côte d'Ivoire. International Journal of Biological and Chemical Sciences 5(3):1201-1214

Tchabi V, Adechi KO (2014). Occupation des terres, typologie et structure des faciès de végétation à Vitellaria paradoxa (Gaertn F.) de la Commune de Toukountouna au Nord-Bénin. International Journal of Biological and Chemical Sciences 8(4): 1684-1696.

Vaughan DA, Balazs E, Heslop-Harrison JS (2007). From crop domestication to super-domestication. Annals of Botany 100(5):893901.

Yace I (2002). Initiation à la géologie. L"exemple de la Côte d"Ivoire et de I"Afrique de I"Ouest. Pétrologie, Géologie régionale. Ed. CEDA, SODEMI $p 183$.

Yao SDM, Konan JL, Sie R, Diarrassouba N, Lekadou TT, Koffi EBZ, Yoboue K, Bourdeix R, Issali AE, Doh F, Allou K, Zoro Bi IA (2015). Fiabilité d'une liste minimale de descripteurs agromorphologiques recommandée par le COGENT dans l'étude de la diversité génétique du cocotier (Cocos nucifera L.). Journal of Animal and Plant Sciences 26 (1):4006-4022.

Yao SDM, Alui KA, Kouame NMT, Ble PA, Kone B, Diarrassouba N (2019). Réussir le " greffage en fente simple » et le " greffage de côté dans l'aubier " du karité. Journal of Applied Biosciences 137(1):13961-13972. 